\title{
Urinary Tract Infection During Pregnancy: Prevalence, Associated Risk Factors and Treatment Outcome Based on Antimicrobial Sensitivity Pattern
}

\author{
Pragya Lakshmi $^{1,2 *}$, Ranjan Kumar Srivastava $^{2}$ and Alok Bharadwaj ${ }^{1}$ \\ ${ }^{1}$ Department of Biotechnology and Microbiology, GLA University, Mathura - 281 406, India. ${ }^{2}$ Department of \\ Microbiology, Patna Medical College, Patna - 800 004, India.
}

\begin{abstract}
Urinary tract infection is common among pregnant women. It can be either asymptomatic or symptomatic. This study was done on 225 pregnant women which comprised of both asymptomatic and symptomatic urinary tract infection in the Department of Microbiology Patna Medical College and Hospital, Patna and Department of Biotechnology and Microbiology GLA University, Mathura. The prevalence of asymptomatic bacteriuria in the present study was $7.42 \%$, while for symptomatic cases it was $\mathbf{7 6 \%}$. E.coli was the commonest organism responsible for bacteriuria. Semi quantitative culture remains the gold standard for detecting bacteriuria. Of the different antibiotics used Amikacin, Nitrofurantoin, Meropenem, Piperacillin-Tazobactum were the most effective drugs in order to treat bacteriuria.
\end{abstract}

Keywords: UTI, Bacteriuria, Semi quantitative culture, E.coli, Screening tests.

*Correspondence: pragya.lakshmi92@gmail.com

(Received: 12 January 2019; accepted: 22 February 2019)

Citation: Pragya Lakshmi, Ranjan Kumar Srivastava and Alok Bharadwaj, Urinary Tract Infection During Pregnancy: Prevalence, Associated Risk Factors And Treatment Outcome Based on Antimicrobial Sensitivity Pattern, J Pure Appl Microbiol., 2019; 13(1): 561-565 doi: 10.22207/JPAM.13.1.63

(c) The Author(s) 2019. Open Access. This article is distributed under the terms of the Creative Commons Attribution 4.0 International License which permits unrestricted use, sharing, distribution, and reproduction in any medium, provided you give appropriate credit to the original author(s) and the source, provide a link to the Creative Commons license, and indicate if changes were made. 


\section{INTRODUCTION}

During pregnancy urinary tract infection is one of the commonest infection encountered in clinical practice. It may be asymptomatic or symptomatic. Asymptomatic bacteriuria which is also known as covert bacteriuria is defined as finding more than $10^{5}$ colony forming units on culture of urinary samples from pregnant women. Symptomatic bacteriuria presents with symptoms like dysuria, fever, abdominal pain, urgency, increased frequency of micturition. Untreated ASB can lead to symptomatic cystitis in approximately $30 \%$ of patients and Pyelonephritis in $50 \%$ of patients ${ }^{1}$. Semiquantitative urine culture of midstream urine sample is the gold standard in screening and diagnosis of bacteriuria ${ }^{2}$. The prevalence of asymptomatic bacteriuria from reported studies is $2-11 \%^{3}$. There are varied physiological, anatomical and hormonal factors responsible for urinary tract infection during pregnancy. Commonest organism responsible are E.coli followed by Klebsiella, Proteus, coagulase negative staphylococci and Pseudomonas ${ }^{4-8}$. Untreated bacteriuria can lead to low birth weight infants and preterm birth. Different screening tests has been tried to detect bacteriuria during pregnancy but none was found to be adequate to replace semiquantitative urine culture. It has been found that antibiotic treatment reduces the incidence of adverse perinatal outcomes and various maternal complications.

\section{Associated Risk Factors}

The risk factors include short urethra and its proximity to the anal canal which predisposes to bacterial colonization. Certain hormonal changes which occur during pregnancy which results in smooth muscle relaxation of ureter and bladder, leading to dilation of ureter and increased ureterovesical reflux. Pressure of the foetus on the ureter causes obstruction to the ureters leading to statis and infection. Glycosuria during pregnancy may be an additional factor.

\section{MATERIAL AND METHODS}

This prospective study was conducted on pregnant women with both asymptomatic and symptomatic urinary tract infection in the department of Microbiology Patna Medical College and Hospital, Patna and department of
Biotechnology and Microbiology GLA University, Mathura . Pregnant women of varying gestational period coming for antenatal check up in the outpatient department and admitted in the obstetrics and Gynaecology Department during the period from March 2017 to December 2017 were studied .Informed consent was obtained for participation in this study.

\section{Sample Size}

A total of 225 pregnant women were studied.

\section{Sample Collection}

A clean catch midstream urine sample was collected in a sterile universal container.

\section{Investigations}

Samples thus collected were subjected to urine microscopy and culture was done by semiquantitative method on MacConkey and Cystine Lactose Electrolyte Deficient (CLED) medium by using a calibrated loop and incubated at 37 degree Celsius. Gram staining, Motility test, catalase test, oxidase test, coagulase test and different biochemical tests were done for organism identification.

Antibiotic sensitivity tests was done by Kirby- Bauer method on nutrient agar and Muller Hinton agar plate.

\section{RESULTS}

\section{Urine Microscopy for Pyuria}

Out of 175 aymptomatic bacteriuria studied sample 47 (26.85\%) were micro-scopically positive and $128(73.14 \%$ ) were negative (Table 1$)$.

Out of 50 symptomatic pregnant women studied sample $41(82 \%)$ were microscopically positive and $9(18 \%)$ were negative (Table 2 ).

Findings of Culture for Asymptomatic Bacteriuria cases

Out of 175 Studied Sample 13 (7.42\%) were culture positive and $162(92.58 \%)$ were culture negative (Table 3 ).

Findings of Culture for Symptomatic Pregnant Women

Out of 100 studied sample $38(76 \%)$ were culture positive and $12(24 \%)$ were culture negative (Table 4).

\section{Commonest Pathogen Isolated}

The commonest pathogen isolated was

E.coli (Table 5). 
Table 1. Urine Microscopy for Asymptomatic Bacteriuria

\begin{tabular}{lcc}
\hline Microscopy & Number & Percentage \\
\hline Positive & 47 & 26.85 \\
Negative & 128 & 73.14 \\
Total & 175 & 100 \\
\hline
\end{tabular}

Table 2. Urine Microscopy for Symptomatic Pregnant women

\begin{tabular}{lcc}
\hline Microscopy & Number & Percentage \\
\hline Positive & 41 & 82 \\
Neagtive & 9 & 18 \\
Total & 50 & 100 \\
\hline
\end{tabular}

Table 3. Culture for Asymptomatic Bacteriuria

\begin{tabular}{lcc}
\hline $\begin{array}{l}\text { Asymptomatic } \\
\text { bacteriuria }\end{array}$ & Number & Percentage \\
\hline Culture Positive & 13 & 7.42 \\
Culture Negative & 162 & 92.58 \\
Total & 175 & 100 \\
\hline
\end{tabular}

Table 4. Findings of Culture for Symptomatic Pregnant women

\begin{tabular}{lcc}
\hline $\begin{array}{l}\text { Symptomatic } \\
\text { Bacteriuria }\end{array}$ & Number & Percentage \\
\hline Culture Positive & 38 & 76 \\
Culture Negative & 12 & 24 \\
Total & 50 & 100
\end{tabular}

Table 5. Bacterial isolates in asymptomatic and symptomatic Bacteriuric cases.

\begin{tabular}{|c|c|c|}
\hline Organisms & $\begin{array}{l}\text { No. of } \\
\text { cases }\end{array}$ & Percentage \\
\hline E. coli & 30 & 56.66 \\
\hline Klebsiella pneumoniae & 8 & 15.09 \\
\hline Coagulase negative & 5 & 9.43 \\
\hline \multicolumn{3}{|l|}{ Staphylococcus } \\
\hline Staphylococcus aureus & 3 & 5.66 \\
\hline Pseudomonas aeruginosa & 2 & 3.77 \\
\hline Proteus mirabilis & 4 & 7.54 \\
\hline Candida & 1 & 1.88 \\
\hline Total & 53 & 100.00 \\
\hline
\end{tabular}

Table 6. Antibiotic Sensitivity test

\begin{tabular}{|c|c|c|c|c|c|c|c|}
\hline & $\begin{array}{l}\text { E.coli } \\
(30)\end{array}$ & $\begin{array}{l}\text { Klebsiella } \\
\text { spp. (8) }\end{array}$ & $\begin{array}{l}\text { Coagulase } \\
\text { Negative } \\
\text { Staph(5) }\end{array}$ & $\begin{array}{c}\text { S.aureus } \\
\text { (3) }\end{array}$ & $\begin{array}{l}\text { Pseudomonas } \\
\text { spp.(2) }\end{array}$ & $\begin{array}{l}\text { Proteus } \\
\text { spp.(4) }\end{array}$ & $\begin{array}{c}\text { Candida } \\
\text { (1) }\end{array}$ \\
\hline Ampicillin & $1(3.33 \%)$ & 0 & $1(20 \%)$ & 0 & 0 & $1(25 \%)$ & 0 \\
\hline $\begin{array}{l}\text { Amoxycillin } \\
\text { Clavulanic acid }\end{array}$ & $4(13.33 \%)$ & 0 & $2(40 \%)$ & $1(33.33 \%)$ & 0 & $1(25 \%)$ & 0 \\
\hline Amikacin & $24(80 \%)$ & $5(62.5 \%)$ & 0 & $1(33.33 \%)$ & $1(50 \%)$ & $2(50 \%)$ & 0 \\
\hline Cotrimoxazole & $12(40 \%)$ & $2(25 \%)$ & $2(40 \%)$ & $1(33.33 \%)$ & 0 & $2(50 \%)$ & 0 \\
\hline Cephalexin & $5(16.66 \%)$ & $2(25 \%)$ & $3(60 \%)$ & $1(33.33 \%)$ & 0 & 0 & 0 \\
\hline Ceftriaxone & $6(20 \%)$ & $2(25 \%)$ & $3(60 \%)$ & $1(33.33 \%)$ & 0 & 0 & 0 \\
\hline Meropenem & 19(63.33\%) & $6(75 \%)$ & $4(80 \%)$ & $2(66.66 \%)$ & $1(50 \%)$ & $1(25 \%)$ & 0 \\
\hline Nitrofurantoin & $21(70 \%)$ & $6(75 \%)$ & $3(60 \%)$ & $1(33.33 \%)$ & 0 & $1(25 \%)$ & 0 \\
\hline $\begin{array}{l}\text { Piperacillin } \\
\text { Tazobactum }\end{array}$ & $16(53.33 \%)$ & $4(50 \%)$ & $2(40 \%)$ & $1(33.33 \%)$ & 0 & $1(25 \%)$ & 0 \\
\hline $\begin{array}{l}\text { Cefoperazone } \\
\text { Sulbactum }\end{array}$ & $18(60 \%)$ & $5(62.5 \%)$ & $1(20 \%)$ & $1(33.33 \%)$ & $1(50 \%)$ & $1(25 \%)$ & 0 \\
\hline
\end{tabular}

\section{Treatment Outcome}

The pregnant women treated as per Culture and sensitivity report were followed up for recurrence of symptoms during pregnancy. Repeat urine culture was done after 15 days of completion of antimicrobial therapy. All treated pregnant women were found to be cured of bacteriuria after initial antimicrobial therapy, however 30 pregnant women(13.33\%) again became symptomatic and routine urine microscopy and culture was done 
and were treated as per sensitivity report. They were also advised to get thoroughly investigated after delivery for urinary tract abnormalities.

\section{DISCUSSION}

The prevalence of asymptomatic bacteriuria in the present study was $7.42 \%$ (13/175), while for symptomatic cases it was $76 \%$ $(38 / 50)$. This is within the reported range of 3-10\% by other workers. Mathew et al, 1998 reported a prevalence of $6.8 \%$ in his study at Christian Medical College, Vellore ${ }^{9}$ and Lavanya et al, 2002 reported prevalence of $8.4 \%$ in a study at AIIMS Delhi ${ }^{10}$. Studies conducted in different countries like, Ehopia (1998), USA (2000), Malaysia (2002), Turkey( 2005), Iran (2007) showed a prevalence of 3-10\% ${ }^{11,12,13,14,15}$.

Bacterial detection by microscopy in asymptomatic cases was $26.85 \%$ while in symptomatic group it was $82 \%$ this is in line with findings of other studies.

Commonest organism isolated in this study was E.coli (56\%) followed by Klebsiella (15\%). Other organisms isolated were Coagulase negative Staphylococci (9.4\%), Staphylococcus aureus (5.6\%), Pseudomonas spp (3.7\%), Proteus $\operatorname{spp}(7.5 \%)$ and Candida (1.8\%). Gayathree et al from Karnataka found E.coli in $51.6 \%$ of samples from asymptomatic pregnant women and Staphylococcus and Klebsiella in $9.6 \%$ of cases ${ }^{16}$. In another study by Kheya Mukherjee et al from West Bengal, E.coli was the commonest organism isolated $(57.14 \%)^{17}$. Study conducted by Nithyasree et al, from Tamil Nadu E.coli was isolated in $65.11 \%$ followed by Klebsiella and Staphylococcus aureus in $11.62 \%$ cases $^{18}$.

Of the different antibiotics used for the sensitivity tests most effective antimicrobials for E.coli found in this study were Amikacin (80\%), Nitrofurantoin (70\%), Meropenem (63.3\%), Piperacillin- tazobactum (53.3\%) while Ampicillin was the least sensitive drug. This finding is almost similar to findings of Anu Mary Bose et al from Kerala ${ }^{19}$.

\section{CONCLUSION}

This study was done on 225 samples which comprised of both asymptomatic and symptomatic bacteriuria. Our study showed E.coli as the commonest organism. Screening of all pregnant women should be done during their first antenatal visit followed by urine culture in order to detect bacteriuria. Pregnant women who are detected with bacteriuria should be treated with appropriate antibiotics based on the antibiotics sensitivity tests. Educational status and level of personal hygiene of all women should be improved specially those belonging to low socio-economic group in order to eradicate bacteriuria.

\section{ACKNOWLEDGEMENTS}

None.

\section{CONFLICT OF INTEREST}

The author declares that there are no conflict of interest.

\section{REFERENCES}

1. Harris RE, The significance of eradication of bacteriuria during pregnancy. Obstet Gynecol., 1979; 53:71-3.

2. Gayathree L, Shetty S, Deshpande SR, Venkatesha DT. Screening for asymptomatic bacteriuria in pregnancy: an evaluation of various screening tests at the Hassan District Hospital, India. J Clinic Diagno Res. 2010; (4): 2702-6.

3. Mclsaac W, Carroll JC, Biringer A, Bernstein P, Lyons E, Low DE, et al. Screening for ASB in pregnancy. J Obstet Gynaecol Can., 2005; 27:20-4.

4. Lavanya SV, Jogalakshmi D. Asymptomatic bacteriuria in antenatal women. Indian J Med Microbiol., 2002; 20(2): 105-6.

5. Colgan R, Nicolle LE, Mcglone A, Thomas M. Hooton. Asymptomatic bacteriuria in adults. Am Family Physician., 2006; 74(6): 985-90.

6. Imade PE, Izekor PE, Eghafona NO, Enabulele OI, Ophori E. Asymptomatic bacteriuria among pregnant women. N Am J Med Sci., 2010; 2(6): 263-6

7. Demilie T, Beyene G, Melaku S, Tsegaye W. Urinary bacterial profile and antibiotic susceptibility pattern among pregnant women in north west ethiopia. Ethiop J Health Sci., 2012; 22(2): 121-8.

8. Jain V, Das V, Agarwal A, Pandey A. Asymptomatic bacteriuria and obstetric outcome following treatment in early versus late pregnancy in north Indian women. Indian J Med Res., 2013; 137(4):753-8.

9. Mathews JE, George S, Mathews P, Mathai E, Brahmadathan KN, Seshadri L. The Griess test: An inexpensive test for asymptomatic bacteriuria in pregnancy. Aust NZ J Obstet Gynaecol 1998; 38 (4): 407-10.

10. Lavanya SV, Jogalakshmi D. Asymptomatic bacteriuria in antenatal women. Indian J Med Microbiol., 2002; 20(2): 105-6.

11. Mohammad M, Mahdy ZA, Omar J, Maan N, Jamil MA. Laboratory aspects of asymptomatic bacteriuria in pregnancy. The Southeast Asian Journal of Tropical Medicine and Public Health, 2002; 33: 575-580.

12. Gebre-Selassie S. Asymptomatic bacteriuria in 
pregnancy: Epidemiological,clinical and microbiological approach. Ethiop Med J., 1998; 36(3): 18592.

13. Hazhir S. Asymptomatic bacteriuria in pregnant woman. Urology J., 2007; 4(1): 24-7.

14. Tugrul S, Oral O, Kumru P. Kose D, Alkan A, Vildirim G. Evaluation an importance of asymptomatic bacteriuria in pregnancy. Clin Exp Obstet Gynecol., 2005; 32(4): 237-40.

15. Mc Nair RD, MacDonald SR, Dooley SL, Peterson LR. Evaluation of the centrifuged and Gram-stained smear, urinalysis, and reagent strip testing to detect asymptomatic bacteriuria in obstetric patients. Am J Obstet Gynecol 2000; 182(5): 1076-9.

16. Gayathree L, Shetty S, Deshpande SR, Venkatesha DT. Screening for asymptomatic bacteriuria in pregnancy: an evaluation of various screening tests at the Hassan District Hospital, India. J Clinic Diagno Res., 2010; (4): 2702-6.

17. Mukherjee K, Golia S, Vasudha CL, Babita, Bhattacharjee D, Chakroborti G. A study on asymptomatic bacteriuria in pregnancy: prevalence, etiology and comparison of screening methods. Int J Res Med Sci., 2014; 2(3): 1085-91.

18. Nithyalakshmi J, Vijayalakshmi. Bacterial profile and antibiogram pattern of UTI in pregnant women at tertiary care teaching hospital. Int J Pharma and Bio Sci. 2014;5(4):201-7.

19. Bose AM, Sreekumary PK, Pulikkottil SK. Microbiological profile of asymptomatic bacteriuria in pregnancy. Int J Reprod Contracept Obstet Gynecol., 2017; 6: 1352-61. 